\title{
THE USE OF DERIVATIONAL SUFFIXES STRATEGY TO ENHANCE STUDENTS' MORPHOLOGICAL AWARENESS OF VOCABULARY MASTERY AT SMP SANTO PETRUS MEDAN IN THE ACADEMIC YEAR 2017/2018
}

BY:

\author{
KARISMA ERIKSON TARIGAN ${ }^{1}$, MARGARET STEVANI ${ }^{2}$ \\ (CATHOLIC UNIVERSITY OF SAINT THOMAS MEDAN ${ }^{1,2}$ )
}

\begin{abstract}
Vocabulary learning plays an important role in vocabulary acquisition, one possible way to achieve it is by using derivational suffixes. The purpose of the study is to know the students' responses after they are taught with affixation strategy. The subject of this study is the students of Class IX-1 of SMP Santo Petrus Medan in the academic year of 2017/2018. This study is conducted by applying descriptive qualitative research and in the form of survey research. (The instruments of collecting data are quantitative data (questionnaire) and qualitative data (field notes). The result of questionnaire shows that most of the students choose item Strongly Agree whose percentage is $85.79 \%$ and item Agree whose percentage is $14.20 \%$. This finding proves that the students' learning behavior changed positively, that is, their attitude and motivation heightened significantly by using derivational suffixes strategy to teach vocabulary. The data of students' morphological awareness response of the use of derivational suffixes shows that: (1) Affixation helps to remember English vocabulary better, (2) Affixation helps connect vocabulary with its meaning, (3) Affixation helps to develop vocabulary, (4) Affixation helps to recognize noun, verb, adjective, and adverb, (5) Affixation helps to separate form and meaning between root and affix, (6) The rules of affixation make students understand the good spelling of vocabulary, and (7) Affixation supports English learning. These indicate that there is a significant improvement of the students' vocabulary mastery through derivational suffixes strategy of Class IX-1 of SMP Santo Petrus Medan in the academic year of 2017/2018.
\end{abstract}

Keywords: vocabulary mastery, affixation, derivational suffixes strategy, morphological awareness, descriptive qualitative research.

\section{INTRODUCTION}

The Background of The Study

English is an international language and in Indonesia it is the first foreign language taught from kindergarten to university level. Language skills such as listening, speaking, reading, and writing as well as element such as vocabulary 
and structures must be taught to students since all languages have a set of words which is the basis to understand and make sentences. Ericcson, et. al. (2018:635) state that without a large enough vocabulary, neither language production nor language comprehension is possible. Gass, et. al. (2020:237) states that the number of words for which the learner has at least some knowledge or meaning, and depth of vocabulary knowledge as reflecting how well a learner knows individual words or how well words are organized in the learner's mental lexicon.

Learning vocabulary is closed to a grammatical element within a word, that is affixation. Nation (2001:63) states that knowing a word can involve knowing that it is made up of affixes and a stem that can occur in other words. Kim (2013:45) states that the implementation of morphological competence in derivational affixation learning improves students' vocabulary acquisition. Derivational affixation can occur with unlimited set of words. Maharsi and Purwaningtyas (2017:26) state that derivational morpheme is a type of bound morpheme which develops or creates new words by either changing the class of words or forming new words. Based on these statements, as long as individuals who are learning English as a second language realize morphemes in complex words, they may learn and acquire vocabulary easily.

Relevant researches had been done to examine affixation in improving vocabulary. The first research was conducted by Zhang and Koda (2012) in their studies to show the correlation between morphological awareness and vocabulary knowledge in L2 acquisition tested the direct and the indirect effects of morphological awareness of adult Chinese readers on second language vocabulary knowledge. Based on the study results, they found that some effect of 
morphological awareness on EFL vocabulary knowledge was realized via learners' skill to integrate structural (derivational morphology) and semantic (morpheme meaning) information to infer meanings of unknown complex words. Moreover, learners can use the syntactic signals provided by suffixes in derived words to help parse complex sentences, which could also contribute to comprehension. The second research was conducted by Kim (2013) entitled "Vocabulary Acquisition with Affixation: Learning English Words based on Prefixes and Suffixes" stating that affixation strategy can help students learn English vocabulary mastery much faster.

Teaching vocabulary is not a simple task. Almost everyone realizes that teaching vocabulary only wastes time because vocabulary number is unlimited. Zeh (2016:4) states that students cannot learn to spell words solely by sounding them out because a single letter in English can represent more than one sound. Knowledge of morphemes can make spelling of complex words or spelling exceptions easier for students to remember. Dealing with the fact, one possible way to broaden vocabulary is by using affixation. Most of affixation can be found in an English text. Based on the writer's observation in SMP Santo Petrus Medan, it was found out that those students had difficulties in learning vocabulary. They made mistakes in interpreting the meaning of word in the sentence because it contains an affix. When the teacher asked the meaning of the word 'visitor' they were silent and no one spoke in the classroom related to this word, but when the teacher says the word 'visit', they knew the meaning and the category of this word. It indicated that students only thought of vocabulary learning as the primary meaning of new words. Therefore, they ignored what categories and the meaning 
of the words were. They did not realize that adding a suffix could change the category of the word. Considering the facts, the writer also conducted the pre-test about vocabulary mastery to the ninth grade students of SMP Santo Petrus Medan. Based on the result of pre-test, all the students of the ninth grade could not pass Minimal Criterion Mastery in English subject whose value is 70 .

Based on the influence of vocabulary in affixation and its urgency in English curriculum, the writer decided to conduct a study entitled "The Use of Derivational Suffixes to Enhance Students' Morphological Awareness of Vocabulary Mastery at SMP Santo Petrus Medan in the Academic Year 2017/2018."

\section{The Problem of Study}

In line with the background of the study, the problem of study is formulated as follow: How do the students' respond after they are taught with affixation strategy?

\section{The Objective of Study}

The objective of study is to know the students' responses after they are taught with affixation strategy.

\section{The Scope of Study}

This study is limited to the use of derivational suffixes in enhancing students' morphological awareness of vocabulary mastery. This affixation focuses on derivational suffixes in nominal, verbal, adjectival, and adverbial which form vocabulary in noun, verb, adjective, and adverb. 


\section{RESEARCH METHOD}

\section{Research Design}

This study aimed to find out the students' responses after they were taught with affixation strategy. The research design was in the form of descriptive qualitative research and it is the part of survey research. A qualitative research method was applied in order to answer the search questions, it was necessary to gain a wide range of information and seek the views, beliefs, and perceptions of the study participants.

According to Ary, et. al. (2010:25) "Descriptive research is to describe and interpret what is. It is concerned with conditions or relationships that exist; practices that prevail; beliefs, points of view, or attitudes that are held; processes that are going on; effects that are being felt; or trends that are developing. Its major purpose is to tell what is." Crowther and Lauesen (2017:329) defined a survey research as a brief interview or discussion with individuals about a specific topic. The broad area of survey research encompasses any measurement procedures that involve asking questions of respondents. It can be administered in a couple of different ways. In one method known as a structured interview, the researcher asks each participant the questions. In the other method known as a questionnaire, the participant fills out the survey on his or her own. Most surveys will combine nominal data on participants' backgrounds and relevant personal details with other scales. Thus, they are useful for gathering factual information, data on attitudes and preferences. 


\section{Location, Subject, and Time of Research}

The research was conducted at SMP Santo Petrus Medan which is located on Jalan Luku No.1 Simpang Pos, Kwala Bekala, Medan Johor, Kota Medan, Sumatera Utara 20146, Indonesia. The subject of research was the ninth grade students of SMP Santo Petrus Medan. The class consists of 30 students, 19 males and 11 females. The cycle I and cycle II were carried out on May and July in the second semester in the academic year of 2017/2018.

\section{DATA ANALYSIS}

\section{Data Analysis}

This chapter presents the data gathered from the actions. The data consists of questionnaire and field notes. The following are the analysis of questionnaire data:

\section{Analysis of Questionnaire}

The analysis of questionnaire is presented by using the formula:

$M=\frac{\Sigma \mathrm{x}}{N} \mathrm{x} 100 \%$

Where: $\mathrm{M}=$ the mean of students' questionnaire

$\sum X=$ the total of students' choice (frequency)

$\mathrm{N}=$ the total number of students who are given the questionnaire

Table 1 The Analysis of Questionnaire

\begin{tabular}{|c|l|l|c|c|c|}
\hline No. & \multicolumn{1}{|c|}{$\begin{array}{c}\text { Number } \\
\text { List of Items }\end{array}$} & \multicolumn{1}{|c|}{$\begin{array}{c}\text { Scale } \\
\text { Value }\end{array}$} & Frequency & $\begin{array}{c}\text { Percentage } \\
(\mathbf{\%})\end{array}$ & Category \\
\hline 1. & $\begin{array}{l}\text { Affixation helps } \\
\text { to Strongly Disagree }\end{array}$ & 0 & $0 \%$ & \\
\cline { 2 - 4 } & English remember & Disagree & 0 & $0 \%$ & \multirow{2}{*}{ High } \\
\cline { 2 - 5 } & Undecided & 0 & $0 \%$ & $0 \%$ \\
\hline
\end{tabular}




\begin{tabular}{|c|c|c|c|c|c|}
\hline \multirow{2}{*}{\multicolumn{2}{|c|}{ vocabulary better. }} & Agree & 9 & $30 \%$ & \\
\hline & & Strongly Agree & 21 & $70 \%$ & \\
\hline \multirow[t]{5}{*}{2.} & \multirow{5}{*}{$\begin{array}{l}\text { Affixation } \\
\text { connect } \\
\text { vocabulary } \\
\text { its meaning. }\end{array}$} & Strongly Disagree & 0 & $0 \%$ & \multirow{5}{*}{ High } \\
\hline & & Disagree & 0 & $0 \%$ & \\
\hline & & $\sqrt{\text { Undecided }}$ & $\overline{0}$ & $0 \%$ & \\
\hline & & Agree & 5 & $16.66 \%$ & \\
\hline & & Strongly Agree & 25 & $83.33 \%$ & \\
\hline \multirow[t]{5}{*}{3.} & Affixation helps & Strongly Disagree & 0 & $0 \%$ & \multirow{5}{*}{ High } \\
\hline & \multirow{4}{*}{$\begin{array}{l}\text { to develop } \\
\text { vocabulary. }\end{array}$} & Disagree & 0 & $0 \%$ & \\
\hline & & Undecided & 0 & $0 \%$ & \\
\hline & & Agree & 9 & $30 \%$ & \\
\hline & & Strongly Agree & 21 & $70 \%$ & \\
\hline \multirow[t]{5}{*}{4.} & \multirow{5}{*}{$\begin{array}{l}\text { Affixation helps } \\
\text { to recognize noun, } \\
\text { verb, adjective, } \\
\text { and adverb. }\end{array}$} & Strongly Disagree & 0 & $0 \%$ & \multirow{5}{*}{ High } \\
\hline & & Disagree & 0 & $0 \%$ & \\
\hline & & Undecided & 0 & $0 \%$ & \\
\hline & & Agree & 5 & $16.66 \%$ & \\
\hline & & Strongly Agree & 25 & $83.33 \%$ & \\
\hline \multirow[t]{5}{*}{5.} & \multirow{5}{*}{$\begin{array}{ll}\text { Affixation } & \text { helps } \\
\text { to separate form } \\
\text { and } & \text { meaning } \\
\text { between root and } \\
\text { affix. }\end{array}$} & Strongly Disagree & 0 & $0 \%$ & \\
\hline & & Disagree & 0 & $0 \%$ & \\
\hline & & Undecided & 0 & $0 \%$ & \\
\hline & & Agree & 3 & $10 \%$ & \\
\hline & & Strongly Agree & 27 & $90 \%$ & \\
\hline \multirow[t]{5}{*}{6.} & The rules of & Strongly Disagree & 0 & $0 \%$ & \multirow{5}{*}{ High } \\
\hline & \multirow{4}{*}{$\begin{array}{l}\text { affixation make } \\
\text { you understand } \\
\text { the good spelling } \\
\text { of vocabulary. }\end{array}$} & Disagree & 0 & $0 \%$ & \\
\hline & & Undecided & 0 & $0 \%$ & \\
\hline & & Agree & 2 & $6.66 \%$ & \\
\hline & & Strongly Agree & 28 & $93.33 \%$ & \\
\hline \multirow[t]{5}{*}{7.} & \multirow{5}{*}{$\begin{array}{l}\text { Affixation } \\
\text { supports English } \\
\text { learning. }\end{array}$} & Strongly Disagree & 0 & $0 \%$ & \multirow{5}{*}{ High } \\
\hline & & Disagree & 0 & $0 \%$ & \\
\hline & & Undecided & 0 & $0 \%$ & \\
\hline & & Agree & 3 & $10 \%$ & \\
\hline & & Strongly Agree & 27 & $90 \%$ & \\
\hline
\end{tabular}

1. Total percentage of item Strongly Disagree:

$\frac{\text { Total item Strongly Disagree }}{\text { Total of scale value }} \times 100 \%=\frac{0}{1014} \times 100 \%=0 \%$

2. Total percentage of item Disagree:

$\frac{\text { Total item Disagree }}{\text { Total of scale value }} \times 100 \%=\frac{0}{1014} \times 100 \%=0 \%$

3. Total percentage of item Undecided:

$\frac{\text { Total item Undecided }}{\text { Total of scale value }} \times 100 \%=\frac{0}{1014} \times 100 \%=0 \%$ 
4. Total percentage of item Agree:

$\frac{\text { Total item Agree }}{\text { Total of scale value }} \times 100 \%=\frac{144}{1014} \times 100 \%=14.20 \%$

5. Total percentage of item Strongly Agree:

$$
\frac{\text { Total item Strongly Agres }}{\text { Total of scale value }} \times 100 \%=\frac{870}{1014} \times 100 \%=85.79 \%
$$

Graphic 1 The Result of Students' Questionnaire

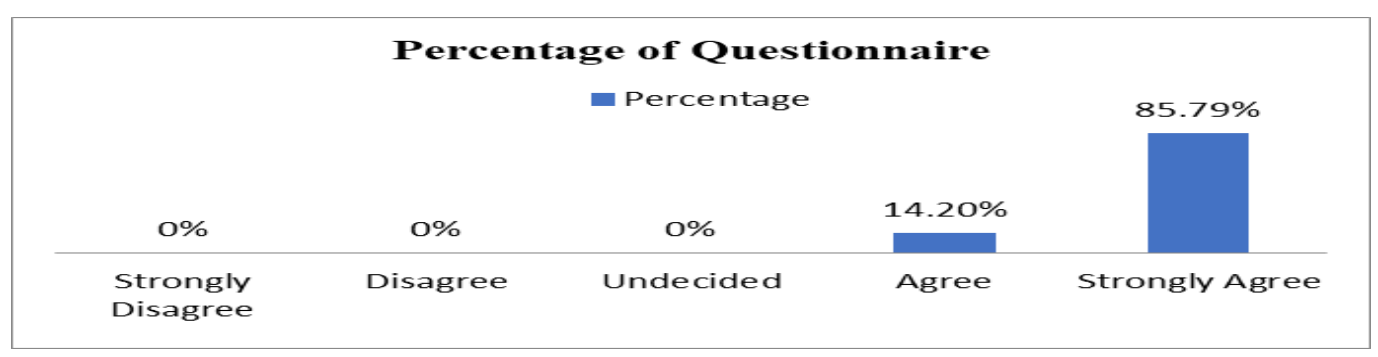

The results of questionnaire shows that the comparison percentage of the student who chose item Strongly Disagree is $0 \%$, the student who chose item Disagree is $0 \%$, the student who chose item Undecided is $0 \%$, the students who chose item Agree are 14.20\%, and the students who chose item Strongly Agree are $85.79 \%$. The comparison percentage of all items of questionnaire shows that the subjects' positive motivation in learning vocabulary mastery. It proves the effectiveness of affixation strategy to improve the students' vocabulary mastery of Class IX-1 of SMP Santo Petrus Medan.

\section{Analysis of Field Notes}

The analysis of field notes to support questionnaire data can be described as follows:

1. Response to statement 1: Affixation helps to remember English vocabulary better. 


\begin{tabular}{|l|l|}
\hline \multicolumn{1}{|c|}{ Students } & \multicolumn{1}{c|}{ Answers } \\
\hline Student A & $\begin{array}{l}\text { Yes, of course. I can remember the words. For example: } \\
\text { beauty, beautify, beautiful, and beautifully. }\end{array}$ \\
\hline Student B & $\begin{array}{l}\text { Yes. The strategy is new to me and implementing this } \\
\text { strategy makes me remember more vocabularies. }\end{array}$ \\
\hline Student C & $\begin{array}{l}\text { Yes. I hope that I never look up the dictionary when I see } \\
\text { the simple words, so that I can enjoy English movies. }\end{array}$ \\
\hline Student D & $\begin{array}{l}\text { Yes, it is good to strengthen my vocabularies when I made } \\
\text { a conversation orally. }\end{array}$ \\
\hline Student E & $\begin{array}{l}\text { Yes, it is helpful in reading text to guess the meaning of the } \\
\text { sentence and remember the main idea of every sentence. }\end{array}$ \\
\hline
\end{tabular}

Response to statement 2: Affixation helps connect vocabulary with its meaning.

\begin{tabular}{|l|l|}
\hline \multicolumn{1}{|c|}{ Students } & \multicolumn{1}{c|}{ Answers } \\
\hline Student A & Yes, of course. It is very logical. \\
\hline Student B & $\begin{array}{l}\text { Yes, sure. I can see that is practically the same meaning, } \\
\text { but another in the form. }\end{array}$ \\
\hline Student C & Yes, they are connected if you know the base meaning. \\
\hline Student D & $\begin{array}{l}\text { Yes, it is always easier when you know the answers in the } \\
\text { multiple choice and you think 'yes, of course.' It helps me } \\
\text { to know the right answer. }\end{array}$ \\
\hline Student E & $\begin{array}{l}\text { Yes, it makes me to know the sense of meaning when the } \\
\text { word is combined in the form of sentence. }\end{array}$ \\
\hline
\end{tabular}

2. Response to statement 3: Affixation helps to develop vocabulary.

\begin{tabular}{|l|l|}
\hline \multicolumn{1}{|c|}{ Students } & \multicolumn{1}{|c|}{ Answers } \\
\hline Student A & $\begin{array}{l}\text { Yes. I can consciously recognize the many forms of words } \\
\text { based on one word. For example: color, colorless, colorful, } \\
\text { colorfully. }\end{array}$ \\
\hline Student B & $\begin{array}{l}\text { Yes. It leads me to the use of academic vocabulary in } \\
\text { writing text. }\end{array}$ \\
\hline Student C & $\begin{array}{l}\text { Yes. It helps me to improve my academic reading } \\
\text { comprehension. }\end{array}$ \\
\hline Student D & $\begin{array}{l}\text { Yes. It helps me to find the right answer faster when I have } \\
\text { an English test. }\end{array}$ \\
\hline Student E & Yes. I realize that. \\
\hline
\end{tabular}

3. Response to statement 4: Affixation helps to recognize noun, verb, adjective, and adverb. 


\begin{tabular}{|l|l|}
\hline \multicolumn{1}{|c|}{ Students } & \multicolumn{1}{c|}{ Answers } \\
\hline Student A & Yes. I can group words according to their classes. \\
\hline Student B & $\begin{array}{l}\text { Yes. It helps me to recognize what type of word class, the } \\
\text { words in matching form test belongs to, when considering } \\
\text { the sentences. }\end{array}$ \\
\hline Student C & $\begin{array}{l}\text { Yes. I know what is nominal, verbal, adjectival, and } \\
\text { adverbial by realizing the suffixes. For example: suffix -en, } \\
\text {-ize are only for verbal, and suffix -er, -or only for noun. }\end{array}$ \\
\hline Student D & \begin{tabular}{l} 
Yes. I can easily identify the words. \\
\hline Student E
\end{tabular} \\
& $\begin{array}{l}\text { using cards and we should guess the meanings and the } \\
\text { classes of the words. }\end{array}$ \\
\hline
\end{tabular}

4. Response to statement 5: Affixation helps to separate form and meaning between root and affix.

\begin{tabular}{|l|l|}
\hline \multicolumn{1}{|c|}{ Students } & \multicolumn{1}{c|}{ Answers } \\
\hline Student A & $\begin{array}{l}\text { Yes. At first, I judge the meaning of new words by their } \\
\text { affix and then consider the root meaning of the new words. }\end{array}$ \\
\hline Student B & $\begin{array}{l}\text { Yes. Some of suffixes have a meaningful meaning when it } \\
\text { is attached to a base word. For example: -ful means penuh } \\
\text { or -ly means adverb. }\end{array}$ \\
\hline Student C & Yes, if you know the meaning of the root first. \\
\hline Student D & $\begin{array}{l}\text { Yes, I know the meaning of some suffix, such as -or means } \\
\text { person in creator and -able means ability in workable. }\end{array}$ \\
\hline Student E & Yes. I separate root and suffix by using (-). \\
\hline
\end{tabular}

5. Response to statement 6: The rules of affixation make you understand the good spelling of vocabulary.

\begin{tabular}{|l|l|}
\hline \multicolumn{1}{|c|}{ Students } & \multicolumn{1}{|c|}{ Answers } \\
\hline Student A & $\begin{array}{l}\text { Yes. I can write the good spelling of vocabulary based on } \\
\text { the rules. For example: Informate become information, not } \\
\text { informateion. }\end{array}$ \\
\hline Student B & $\begin{array}{l}\text { Yes. I can spell the complex word easily when break down } \\
\text { the complex word into simple word. For example: } \\
\text { hospitalize. }\end{array}$ \\
\hline Student C & $\begin{array}{l}\text { Yes. I know the rules to change the vocabulary in verbal } \\
\text { suffixes. The last word of root is dropped (letter y) and is } \\
\text { changed into letter i. For example: memory + ize } \\
\text { memorize. }\end{array}$ \\
\hline Student D & \begin{tabular}{l} 
Yes. I can pronounce the vocabularies clearly. \\
\hline
\end{tabular}
\end{tabular}


\begin{tabular}{|l|l|}
\hline Student E & Yes. As long as I remember the rules of affixation. \\
\hline
\end{tabular}

6. Response to statement 7: Affixation supports English learning.

\begin{tabular}{|l|l|}
\hline \multicolumn{1}{|c|}{ Students } & \\
\hline Student A & Yes. It is interesting. \\
\hline Student B & Yes. It is good. \\
\hline Student C & Yes, it is. \\
\hline Student D & Yes, it is. \\
\hline Student E & Yes, it is. \\
\hline
\end{tabular}

\section{Discussion}

In this study, the morphological instruction helps the learners to raise their morphological awareness and improve learners' vocabulary knowledge. Based on the analysis of data, the results of research are described as follows:

The data of questionnaire shows that the students' response is high to the use of affixation strategy. More than half of the students choose the scale value Strongly Agree. The comparison of the total response of the questionnaire for item Strongly Disagree is $0 \%$, item Disagree is $0 \%$, item Undecided is $0 \%$, item Agree is $14.20 \%$, and item Strongly Agree is $85.79 \%$. It shows that most of the students' respond are positive to derivational suffixes strategy in learning vocabulary mastery. Thus, the writer concludes that most of the subjects are Strongly Agree with the use of derivational suffixes strategy to enhance students' morphological awareness of vocabulary mastery. 
The data of students' morphological awareness response of the use of derivational suffixes shows that: (1) Affixation helps to remember English vocabulary better with the following explanations: (a) Students can remember the words. For example: beauty, beautify, beautiful, and beautifully, (b) Students hope that they never look up the dictionary when they see the simple words, (c) Students can easily guess the meaning of words when watching English movies, (d) it can strengthen students' vocabularies when they made a conversation orally, (e) it is helpful in reading text to guess the meaning of the sentence and remember the main idea of every sentence. (2) Affixation helps connect vocabulary with its meaning with the following explanations: (a) it is very logical when meaning is combined with suffix, (b) Students can see that the word is practically the same meaning, but another in the form, (c) Students can connect the complex words if they know the base meaning, (d) It is easier to find the right answer when the derivational suffix is in the multiple choice test, (e) It makes the students know the sense of meaning when the word is combined in the form of sentence. (3) Affixation helps to develop vocabulary with the following explanations: (a) Students can consciously recognize the many forms of words based on one word. For example: color, colorless, colorful, colorfully, (b) It leads students to the use of academic vocabulary in writing text, (c) It helps students to improve their academic reading comprehension, (d) It helps students find the right answer faster when they have an English test, (e) Students realize affixation is to develop vocabulary. (4) Affixation helps to recognize noun, verb, adjective, and adverb with the following explanations: (a) Students can group words according to their classes, (b) Students can recognize what type of word class, the words in matching 
form test belongs to, when considering the sentences, (c) Students know what is nominal, verbal, adjectival, and adverbial by realizing the suffixes. For example: suffix -en, -ize are only for verbal, and suffix -er, -or only for noun, (d) Students can easily identify the words, (e) It is interesting when suffix strategy is combined by using cards and students are trying to guess the meanings and the classes of the words. (5) Affixation helps to separate form and meaning between root and affix with the following explanations: (a) At first, students judge the meaning of new words by their affix and then consider the root meaning of the new words, (b) Students realize that some of suffixes have a meaningful meaning when it is attached to a base word. For example: -ful means penuh or -ly means adverb, (c) Students should know the meaning of the root first, (d) Students know the meaning of some suffix, such as -or means person in creator and -able means ability in workable, (e) Students separated root and suffix by using (-). (6) The rules of affixation make students understand the good spelling of vocabulary with the following explanations: (a) Students can write the good spelling of vocabulary based on the rules. For example: Informate become information, not informateion, (b) Students can spell the complex word easily when break down the complex word into simple word. For example: hospitalize, (c) Students know the rules to change the vocabulary in verbal suffixes. The last word of root is dropped (letter y) and is changed into letter i. For example: memory + ize $=$ memorize, (d) Students can pronounce the vocabularies clearly, (e) As long as students remember the rules of affixation. (7) Affixation supports English learning with the following explanations: (a) It is interesting, (b) It is good. 
Based on the data analysis of study, it reveals the use of derivational suffixes strategy is effective to enhance students' morphological awareness of vocabulary mastery of Class IX-1 of SMP Santo Petrus Medan in the academic year of 2017/2018.

\section{CONCLUSION}

\section{Conclusion}

The writer draws the conclusions as follows: The result of questionnaire shows that most of the students choose item Strongly Agree whose percentage is 85.79\% and item Agree whose percentage is $14.20 \%$. This finding proves that the students' learning behavior changed positively, that is, their attitude and motivation heightened significantly by using affixation strategy to teach vocabulary. Thus, the writer concludes that most of the subjects are Strongly Agree with the use of derivational suffixes strategy to enhance students' morphological awareness of vocabulary mastery.

The result of questionnaire is the same with the result of field notes. The data of students' morphological awareness response of the use of derivational suffixes shows that: (1) Affixation helps to remember English vocabulary better with the following explanations: (a) Students can remember the words. For example: beauty, beautify, beautiful, and beautifully, (b) Students hope that they never look up the dictionary when they see the simple words, (c) Students can easily guess the meaning of words when watching English movies, (d) it can strengthen students' vocabularies when they made a conversation orally, (e) it is helpful in reading text to guess the meaning of the sentence and remember the 
main idea of every sentence. (2) Affixation helps connect vocabulary with its meaning with the following explanations: (a) it is very logical when meaning is combined with suffix, (b) Students can see that the word is practically the same meaning, but another in the form, (c) Students can connect the complex words if they know the base meaning, (d) It is easier to find the right answer when the derivational suffix is in the multiple choice test, (e) It makes the students know the sense of meaning when the word is combined in the form of sentence. (3) Affixation helps to develop vocabulary with the following explanations: (a) Students can consciously recognize the many forms of words based on one word. For example: color, colorless, colorful, colorfully, (b) It leads students to the use of academic vocabulary in writing text, (c) It helps students to improve their academic reading comprehension, (d) It helps students find the right answer faster when they have an English test, (e) Students realize affixation is to develop vocabulary. (4) Affixation helps to recognize noun, verb, adjective, and adverb with the following explanations: (a) Students can group words according to their classes, (b) Students can recognize what type of word class, the words in matching form test belongs to, when considering the sentences, (c) Students know what is nominal, verbal, adjectival, and adverbial by realizing the suffixes. For example: suffix -en, -ize are only for verbal, and suffix -er, -or only for noun, (d) Students can easily identify the words, (e) It is interesting when suffix strategy is combined by using cards and students are trying to guess the meanings and the classes of the words. (5) Affixation helps to separate form and meaning between root and affix with the following explanations: (a) At first, students judge the meaning of new words by their affix and then consider the root meaning of the new words, (b) 
Students realize that some of suffixes have a meaningful meaning when it is attached to a base word. For example: -ful means penuh or -ly means adverb, (c) Students should know the meaning of the root first, (d) Students know the meaning of some suffix, such as -or means person in creator and -able means ability in workable, (e) Students separated root and suffix by using (-). (6) The rules of affixation make students understand the good spelling of vocabulary with the following explanations: (a) Students can write the good spelling of vocabulary based on the rules. For example: Informate become information, not informateion, (b) Students can spell the complex word easily when break down the complex word into simple word. For example: hospitalize, (c) Students know the rules to change the vocabulary in verbal suffixes. The last word of root is dropped (letter y) and is changed into letter i. For example: memory + ize $=$ memorize, (d) Students can pronounce the vocabularies clearly, (e) As long as students remember the rules of affixation. (7) Affixation supports English learning with the following explanations: (a) It is interesting, (b) It is good. In conclusion, there is a significant improvement of the students' vocabulary mastery after they are taught with derivational suffixes strategy. It is the effective strategy to improve the students' vocabulary mastery.

\section{Suggestions}

In reference to the discussion of the findings, several points are suggested as follows:

1. For English teachers, English teachers should use derivational awareness for instructed foreign language learners. Each of vocabulary which is taught 
must be recognized with the way to pronounce it. The use of media, such as powerpoint media and flash card can also help English teachers to make the efficient time of teaching and learning.

2. For the students in learning English vocabulary, The students should enrich their vocabulary knowledge from many sources to improve their vocabulary mastery better. They can read English story books, English magazines, dictionary, and many more as their materials for learning vocabulary. They are recommended to use affixation strategy to broaden their vocabulary. They should have a daily note which is containing several of vocabularies. They also have a responsibility to apply the new vocabulary in their daily life in order to retain their memory of the new vocabulary.

3. For other writers, It can be used as a reference and guidance in conducting the same study for obtaining better result. Therefore, it can broaden the new technique to enhance the use of derivational suffixes.

\section{BIBLIOGRAPHY}

Adams, V. 2014. Complex Words in English. New York: Routledge Taylor and Francis Group.

Adeniyi, et. al. 2010. English Morphology. Nigeria: National Open University of Nigeria.

Ary, et. al. 2010. Introduction to Research in Education. Belmont: Wadsworth Cengage Learning.

Bhatti, et. al. 2016. Improving Vocabulary through Affixes at Secondary Level. International E-Journal of Advances in Social Sciences, 2(6), 728-732.

Buis, K. 2004. Making Words Stick: Strategies that Build Vocabulary and Reading Comprehension in the Elementary Grades. Ontario: Pembroke Published Limited. 
Chen, X, Wang, Q, \& Luo, Y.C. 2013. Reading Development and Difficulties in Monolingual and Bilingual Chinese Children. Toronto: Springer.

Crowther, D. \& Lauesen, L. 2017. Handbook of Research Methods in Corporate Social Responsibility. Cheltenham: Edward Elgar Publishing Limited.

Dechaine, et. al. 2012. Linguistics for Dummies. Ontario: John Wiley and Sons Canada.

Don, J. 2014. Morphological Theory and the Morphology of English. Edinburgh: Edinburgh University.

Ericcson, K.A, Hoffman, R.R, Kozbelt, A, \& Williams, A.M. 2018. The Cambridge Handbook of Expertise and Expert Performance. Cambridge: Cambridge University.

Fromkin, V, Rodman, R, \& Hyams, N. 2018. An Introduction to Language. California: Cengage.

Gass, S.M, Behney, J, \& Pionsky, L. 2020. Second Language Acquisition: An Introductory Course. New York: Routledge.

Hamawand, Z. 2011. Morphology in English: Word Formation in Cognitive Grammar. Chennai: Continuum.

Hasegawa, Y. 2015. Japanese: A Linguistic Introduction. Cambridge: Cambridge University.

Helman, L, Ittner, A.C. \& McMaster, K.L. 2019. Assessing Language and Literacy with Bilingual Students. New York: The Guilford Press.

Kail, R.V. 2007. Advances in Child Development and Behavior. London: Academic Press.

Katamba, F. 2005. English Words. London: Routledge Taylor and Francis eLibrary.

Katamba, F. 2015. English Words: Structure, History, Usage. London: Routledge Taylor and Francis Group.

Kim, C. 2013. Vocabulary Acquisition with Affixation: Learning English Words based on Prefixes and Suffixes. International Journal of Second Language Studies. 31(2), 43-80. 
Langford, D.P., \& Cleary, B.A. 1995. Orchestrating Learning with Quality. Wisconsin: ASQ Quality.

Maharsi, E. \& Purwaningtyas, I. 2017. Exploring English Morphology: For Elementary Linguistic Learners. Malang: UB Press.

Mather, N. and Wendling, B.J. 2011. Essentials of Dyslexia Assessment and Intervention. New Jersey: John Wiley and Sons.

Milton, J. 2009. Measuring Second Language Acquisition. Bristol: Multilingual Matters.

Nation, I.S.P. 2001. Learning Vocabulary in Another Language. Cambridge: Cambridge University.

Plag, I. 2002. Word Formation in English. Cambrige: Cambridge University.

Rasinski, et. al. 2008. Greek and Latin Roots: Keys to Building Vocabulary. Huntington Beach: Shell Education.

Shopen, T. 2007. Language Typology and Syntactic Description: Grammatical Categories and the Lexicon. Cambridge: Cambridge University.

Stone, C.A, Siliman, E.R, \& Ehren, B.J, \& Wallach, G.P. 2016. Handbook of Language and Literacy, Second Edition: Development and Disorders. New York: The Guilford Press.

Tinnefeld, T. 2018. Challenges of Modern Foreign Language Teaching: Reflections and Analyses. Saarbrucken: HTW Saar.

Webb, S. 2019. The Routledge Handbook of Vocabulary Studies. Oxon: Routledge.

Yoop, H.K. \& Yoop, R.H. 2008. Vocabulary Instruction for Academic Success. New York: Shell Education.

Zeh, N. 2016. Teaching Morphology to Improve Literacy. Cambrige: Cambridge University.

Zhang, D. \& Koda, K. 2012. Morphological Awareness and Reading Comprehension in a Foreign Language: A Study of Young Chinese EFL Learners. System Journal, 4(4), 901-913. 